\title{
Data report: siliceous microfossil abundance in IODP Expedition 342 sediments ${ }^{1}$
}

\section{Chapter contents}

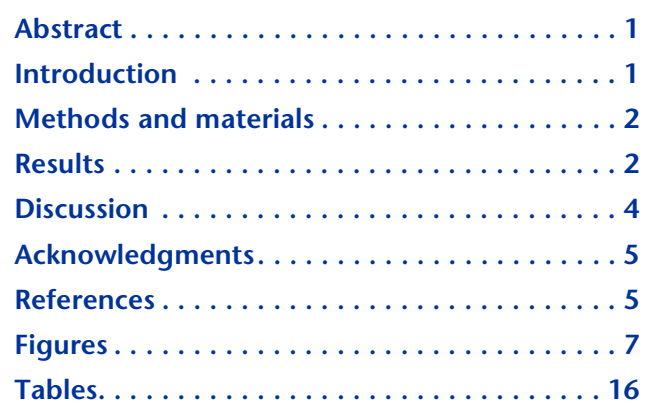

${ }^{1}$ Hollis, C.J., 2017. Data report: siliceous microfossil abundance in IODP Expedition 342 sediments. In Norris, R.D., Wilson, P.A., Blum, P., and the Expedition 342 Scientists, Proceedings of the Integrated Ocean Drilling Program, 342: College Station, TX (Integrated Ocean Drilling Program). doi:10.2204/iodp.proc.342.201.2017

${ }^{2}$ GNS Science, PO Box 30-368, Lower Hutt 5040, New Zealand. c.hollis@gns.cri.nz

Christopher J. Hollis ${ }^{2}$

\begin{abstract}
Siliceous microfossils exhibit an interesting pattern of occurrence in Integrated Ocean Drilling Program Expedition 342 sediments. A review of shipboard data from smear slides and microfossil processing notes was combined with shore-based investigations to provide a revised summary of this occurrence pattern. A review of radiolarian biostratigraphy was also undertaken for all sites. In general, siliceous microfossils (diatoms and radiolarians) are abundant and well preserved in lower Miocene and upper Oligocene drift sediments on the J-Anomaly Ridge (Sites U1404, U1405, and U1406) but are otherwise rare in Neogene to upper Eocene sediments from all sites. Siliceous microfossils (mainly radiolarians) are also abundant in middle Eocene to upper lower Eocene sediments at several sites, tending to be more persistent in the deeper J-Anomaly Ridge sites (U1403 and U1404) than in the shallower sites (U1406 and U1407) and all southeast Newfoundland ridge sites (U1408, U1409, and U1410). No siliceous microfossils were encountered at Site U1411. Sediments are chert rich through the Paleocene-Eocene transition at Sites U1403 and U1407, and as a consequence siliceous microfossils are frequently abundant but always poorly preserved. Well-preserved radiolarians occur in the upper and middle Paleocene at Sites U1403 and U1406-U1409. Hopefully, this record of siliceous microfossil abundance will be helpful in ongoing studies of biosiliceous sedimentation.
\end{abstract}

\section{Introduction}

A robust record of the regional variation in biogenic sediment accumulation rates is needed to understand how climatic and oceanic changes through the Cenozoic may have affected biological productivity and export processes and to better resolve the relationships between climate change and the global carbon cycle. Biogenic opal is a widely used proxy for primary production (e.g., Moore et al., 2008) but is often hard to reliably distinguish from other sources of silica in hemipelagic sediments. Moreover, biogenic silica accumulation is a function of nutrient availability and opal preservation on the seafloor, both of which may vary independently over time (Moore et al., 2014). As with all proxies, it is inadvisable to use this proxy in isolation. Biogenic silica accumulation rate may prove to be a complementary guide to productiv- 
ity when combined with other proxies, such as trace element geochemistry and benthic foraminifers.

This report combines shipboard data from smear slides with shipboard and shore-based data from radiolarian micropaleontology to provide a general guide to the occurrence and abundance of siliceous microfossils (radiolarians and diatoms) in the cores recovered during Integrated Ocean Drilling Program (IODP) Expedition 342 (see the "Expedition 342 summary" chapter [Norris et al., 2014b]). Expedition 342 investigated the Cretaceous-Cenozoic ocean history of the northwest Atlantic (latitude $\sim 41^{\circ} \mathrm{N}$ ) through the recovery of expanded sequences of sedimentary drift deposits deposited in the flanks of J-Anomaly and southeast Newfoundland Ridges (Fig. F1). It is hoped that this overview will improve our understanding of the general controls on biosiliceous sedimentation in this region through the Cenozoic and serve to guide future studies into trends in biogenic sediment accumulation patterns.

The correlation with radiolarian zones has also been reviewed and updated for Sites U1403-U1410 (Figs. F2, F3, F4, F5, F6, F7, F8, F9).

\section{Methods and materials}

The procedure for the description of smear slides is outlined in the "Methods" chapter (Norris et al., 2014a). The following categories are used to quantify the abundance of diatoms and radiolarians in Holes U1403A-U1410A (Table T1):

$$
\begin{aligned}
& 0=\text { absent }(0 \%) . \\
& \mathrm{P}=\text { present }(<1 \%) . \\
& \mathrm{F}=\text { few }(1 \%-10 \%) . \\
& \mathrm{C}=\text { common }(>10 \%-25 \%) . \\
& \mathrm{A}=\text { abundant }(>25 \%-50 \%) . \\
& \mathrm{VA}=\text { very abundant }(>50 \%) .
\end{aligned}
$$

Shipboard processing of radiolarian samples is also outlined in the "Methods" chapter (Norris et al., 2014a). Shore-based processing followed a similar method, except that acid digestion preceded cleaning with $\mathrm{H}_{2} \mathrm{O}_{2}$ and Calgon. Samples were oven dried at $40^{\circ} \mathrm{C}$, weighed, and leached in $10 \%$ hydrochloric acid until the reaction ceased. The spent acid solution was decanted, and the sample was then cleaned by heating on a hot plate in a solution of $10 \% \mathrm{H}_{2} \mathrm{O}_{2}$ and Calgon. After effervescence subsided, the sample was washed through a $63 \mu \mathrm{m}$ sieve. If the residue was not fully clean, the drying, acid leaching, and cleaning steps were repeated. Residues were oven dried at $40^{\circ} \mathrm{C}$ and strewn onto one or more microscope coverslips coated in gum tragacanth. The surface of the coverslip was moistened by a gentle breath, and the loose residue was tapped off. The coverslip was in- verted and gently placed on a slide bearing 8-10 drops of Canada balsam. Radiolarian abundance, preservation, and zonal assignment are listed for Holes U1403A-U1410A in Table T2.

Semiquantitative abundance estimates of the radiolarian assemblage are derived from the number of radiolarians in a $5 \mathrm{~cm}^{3}$ sample:

$$
\begin{aligned}
& \mathrm{A}=\text { abundant }(>10,000) . \\
& \mathrm{C}=\text { common }(2,000-10,000) . \\
& \mathrm{F}=\text { few }(100-1,999) . \\
& \mathrm{R}=\text { rare }(<100) . \\
& \mathrm{B}=\text { barren. }
\end{aligned}
$$

Preservation of the radiolarian assemblage is recorded as

$$
\begin{aligned}
& \mathrm{G}= \text { good (most specimens complete, fine struc- } \\
& \text { tures preserved). } \\
& \mathrm{M}= \text { moderate (minor dissolution and/or break- } \\
& \text { age). } \\
& \mathrm{P}= \text { poor (common dissolution, recrystallization, } \\
& \text { and/or breakage). }
\end{aligned}
$$

The radiolarian biostratigraphy has been reviewed for all samples assigned to radiolarian zones in Table T2. This review was used to refine correlations with radiolarian zones in the stratigraphic summaries (Figs. F2, F3, F4, F5, F6, F7, F8, F9) and age-depth plots (Fig. F10). Radiolarian biostratigraphy is based on the low-latitude zonation outlined by Sanfilippo and Nigrini (1998) and revised by Kamikuri et al. (2012). Age estimates for radiolarian datums have been recalibrated to the GTS2012 timescale (Gradstein et al., 2012).

\section{Results}

The abundance and preservation of radiolarians in microfossil residues and the abundance of diatoms and radiolarians in smear slides is plotted for Sites U1403-U1410 in Figures F2, F3, F4, F5, F6, F7, F8, F9. These data are also recorded in Tables T1 and T2. The key features for each site are summarized below.

\section{Site U1403}

Site U1403 was drilled on the J-Anomaly Ridge in a water depth of $4946.5 \mathrm{~m}$. It was the deepest site drilled during Expedition 342. A poorly dated upper Cenozoic sequence is underlain by a highly siliceous sequence of middle Eocene to Maastrichtian age (Fig. F2).

Radiolarians are abundant and well preserved in the middle Eocene and upper part of the lower Eocene (Cores 342-U1403A-9H through 17H; Zones RP13 through RP9). In the underlying lower Eocene and Paleocene interval (Cores 18X through 25X; Zones 
RP8 through RP6), radiolarian abundance fluctuates from few to abundant and preservation is moderate to poor. Radiolarians are rare but moderately preserved in the lower Paleocene-upper Maastrichtian interval (Cores 26X through 29X). Diatoms are not recorded in smear slides or microfossil residues from this site.

\section{Site U1404}

Site U1404 was drilled on the J-Anomaly Ridge in a water depth of $4746 \mathrm{~m}$. The sediments comprise a condensed, poorly dated, upper Neogene interval underlain by an expanded interval of lower Miocene to middle Eocene drift sediments (Fig. F3).

Siliceous microfossils are abundant in two intervals in Hole U1404A: a lower Miocene to upper Oligocene interval (Cores 342-U1404A-3H through 19H; Zones RN2 through RP21), in which both radiolarians and diatoms are common to abundant, and a middle Eocene interval (Cores $28 \mathrm{H}$ through 36X [bottom of hole]; Zones RP16 through RP14), in which radiolarians are generally abundant but diatoms are absent. Significantly, siliceous microfossils are rare or absent through the Eocene-Oligocene transition at this site.

\section{Site U1405}

Site U1405 was drilled on J-Anomaly Ridge in a water depth of $4286 \mathrm{~m}$. The sediments comprise a short upper Neogene interval underlain by a highly expanded succession of lower Miocene to upper Oligocene drift sediments (Fig. F4).

Siliceous microfossils are absent from the upper Neogene interval but are generally abundant to common and uniformly well preserved in the lower Miocene to upper Oligocene sediments (Cores 342-U1405A$4 \mathrm{H}$ through 29X; Zones RN4 through RP22). Radiolarians decrease in abundance in the lower part of the upper Oligocene interval (Cores 22H through 29X; Zone RP22) but remain well preserved. Diatoms are persistent in Cores $4 \mathrm{H}$ through $29 \mathrm{X}$ and peak in abundance through the Oligocene-Miocene transition (Cores $19 \mathrm{H}$ through $24 \mathrm{H}$ ). Siliceous microfossils are rare or absent from the lower cores (Cores 30X through 33X).

\section{Site U1406}

Site U1406 was drilled on J-Anomaly Ridge in a water depth of $3814 \mathrm{~m}$. It was the shallowest site drilled on J-Anomaly Ridge and recovered an expanded sequence of lower Miocene to middle to upper Eocene drift sediments, which are capped by a condensed sequence of Pliocene-Pleistocene sediments and underlain by Paleocene sediments (Fig. F5).
Siliceous microfossils are generally abundant and well preserved in three intervals within Hole U1406A: a lower Miocene to upper Oligocene interval (Cores 342-U1406A-2H through 15H; Zones RN3 through RP21a), a short middle Eocene interval (Core 29X; Zones RP11 through RP12), and a similarly short upper Paleocene interval (Core 31X; Zone RP7). Radiolarians dominate the siliceous microfossil assemblage, but diatoms are persistent, albeit rare, in both the upper and the Paleocene intervals. As at Site U1404, siliceous microfossils are absent from the Eocene-Oligocene transition interval (Cores $16 \mathrm{H}$ through 27X).

\section{Site U1407}

Site U1407 was drilled on the southeast Newfoundland ridge in a water depth of $3074 \mathrm{~m}$. The sediments comprise a highly condensed Neogene and upper Paleogene succession underlain by a relatively expanded middle Eocene to upper Paleocene succession. The lower $\sim 130 \mathrm{~m}$ of core is a condensed succession that extends from the lower Paleocene to the upper Albian (Fig. F6).

Siliceous microfossils are largely restricted to two intervals in Hole U1407A: a short lower Eocene interval (Cores 342-U1407A-10H through 11H; Zone RP11) and a relatively expanded upper Paleocene interval (Cores 16X through 22X; Zones RP7 through RP6a). Radiolarians are abundant and well preserved in these two intervals. Diatoms are rare in Hole U1407A and are restricted to these two intervals.

\section{Site U1408}

Site U1408 was drilled on southeast Newfoundland ridge in a water depth of $3022 \mathrm{~m}$. It is the shallowest site drilled during this expedition. The sediments comprise a condensed Neogene and upper Paleogene succession underlain by middle Eocene drift sediments, which are in turn underlain by a relatively condensed succession of lower Eocene and upper Paleocene sediments (Fig. F7).

Siliceous microfossils are restricted to two short intervals in Hole U1408A. Abundant and well-preserved radiolarians occur in two cores within the expanded middle Eocene sequence (Cores 342U1408A-16H and 17H; Zone RP13) and two cores in the uppermost Paleocene (Cores 26X and 27X; Zone RP7). Although not recorded in smear slides, radiolarians were also noted in microfossil assemblages directly above these two intervals, but preservation is too poor to confidently identify biostratigraphic marker species. Diatoms are rare in Hole U1408A sediments and are restricted to the two radiolarian-rich intervals. 


\section{Site U1409}

Site U1409 was drilled on southeast Newfoundland ridge in a water depth of $3501.5 \mathrm{~m}$. It is the deepest site drilled at this location. The sediments comprise a relatively condensed Neogene and upper Paleogene succession underlain by middle Eocene drift sediments, which are in turn underlain by a succession of lower Eocene and upper to middle Paleocene sediments (Fig. F8).

Diatoms and radiolarians are common in the uppermost two cores in Hole U1409A (342-U1409A-1H and $2 \mathrm{H}$ ), which are of Pleistocene age. Deeper in Hole U1409A, siliceous microfossils are restricted to two intervals. Radiolarians are generally common and moderately well preserved in the lower Eocene (Cores 12H through 17X; Zones RP11 through RP8) and are abundant and well preserved in the uppermost Paleocene (Cores 20X and 21X; Zones RP7 and RP6c). Diatoms are rare in both intervals and absent from other pre-Pleistocene sediments in Hole U1409A.

\section{Site U1410}

Site U1410 was drilled on southeast Newfoundland ridge in a water depth of $3387 \mathrm{~m}$. The sediments comprise a condensed Neogene and upper Paleogene succession underlain by middle to lower Eocene drift sediments (Fig. F9).

Diatoms and radiolarians are common in the uppermost two cores in Hole U1410A (342-U1410A-1H and $2 \mathrm{H}$ ), which are of undifferentiated PliocenePleistocene age. Deeper in Hole U1410A, siliceous microfossils are restricted to a single lower Eocene interval. Radiolarians are abundant and well preserved in Cores 23X through 26X and span the same Eocene radiolarian zones as in Hole U1409A: Zones RP11 through RP8. Diatoms are rare in this interval and absent from other pre-Pleistocene sediments in Hole U1410A.

\section{Site U1411}

Site U1411 was drilled on southeast Newfoundland ridge in a water depth of $3299 \mathrm{~m}$. Siliceous microfossils are very rare and sporadically distributed at this site.

\section{Discussion}

There is good agreement between paleontological and sedimentological methods for assessing the abundance of siliceous microfossils in Expedition 342 sediments. It is highly unlikely that biogenic opal makes a significant contribution to sediment composition in intervals where siliceous microfossils were not recorded.

There is a consistent pattern in the distribution of siliceous microfossil-rich intervals in Expedition 342 sediment cores (Fig. F10). Siliceous microfossils are common in the Pleistocene in the two deepest sites on southeast Newfoundland ridge (Sites U1409 and U1410; >3300 m water depth) but are otherwise rare in the upper Neogene. Both diatoms and radiolarians are abundant and well preserved in lower Miocene and upper Oligocene drift sediments on the J-Anomaly Ridge (Sites U1404, U1405, and U1406) but are absent from sediments of this age on southeast Newfoundland ridge. Significantly, siliceous microfossils are absent from all sites for $\sim 10 \mathrm{My}$ spanning the Eocene-Oligocene transition, from lower Oligocene to uppermost middle Eocene. Radiolarians are abundant from middle Eocene to upper lower Eocene sediments at several sites, tending to be more persistent in the deeper J-Anomaly Ridge sites (U1403 and U1404) than in shallower sites on J-Anomaly Ridge (U1406 and U1407) and all sites on southeast Newfoundland ridge (U1408, U1409, and U1410). Radiolarians are poorly preserved in a chert-rich interval in the lower Eocene and spanning the Paleocene/Eocene boundary, notably at Sites U1403 and U1407. In contrast, very well preserved, abundant, and diverse radiolarians occur in the upper Paleocene calcareous ooze, which is present at Sites U1406U1409. Indeed, all sites that penetrated the Paleocene in this region encountered a radiolarian-rich interval that encompassed portions of Zones RP6 and $\mathrm{RP7}$, an interval that is also rich in radiolarians at Deep Sea Drilling Project (DSDP) Site 384 (Nishimura, 1992). Preservation is excellent at the shallower sites, where radiolarians occur within the Paleocene nannofossil ooze, but is variable at Site U1403, where sediments are more siliceous.

Diatoms are rare in the lower Paleogene and are restricted to intervals where radiolarians are abundant in the middle to lower Eocene and upper Paleocene. A similar record of siliceous microfossil abundance was recorded at DSDP Site 384, which was drilled on J-Anomaly Ridge at a water depth of 3909 m (Tucholke, Vogt, et al., 1979), where radiolarians are abundant and well preserved from middle to upper lower Eocene (Zones RP11 through RP9) and from upper to lower Paleocene (Zones RP7 through RP6a; Nishimura, 1992). The Paleocene-Eocene transition is not preserved at this site.

This distribution pattern indicates that siliceous microfossil accumulation is greatest during the two main phases of drift sedimentation, particularly the Miocene-Oligocene drifts of J-Anomaly Ridge but 
also in the middle Eocene drifts on southeast Newfoundland ridge and at Sites U1403 and U1404. Radiolarians tend to occur more regularly at deep-water sites (U1403 and U1404) in the Eocene. In the shallower sites, there is a weak trend toward shorter intervals of abundant radiolarian with shoaling. In the Eocene, abundant radiolarians occur over $\sim 3.5 \mathrm{My}$ at Site U1406 $(3814 \mathrm{~m})$, over $\sim 4 \mathrm{My}$ at Sites U1409 $(3502 \mathrm{~m})$ and U1410 $(3387 \mathrm{~m})$, over $\sim 2 \mathrm{My}$ at Site $\mathrm{U} 1407(3074 \mathrm{~m})$, and over $\sim 0.5 \mathrm{My}$ at Site U1408 (3022 m).

In addition to this depth relationship, it also seems likely that the distribution of siliceous microfossil assemblages may be related to the evolution of northwest Atlantic circulation patterns. Siliceous sediments are restricted to the northeast margin of the southeast Newfoundland ridge in the Pleistocene, suggesting that the ridge may mark the oceanographic boundary between Subantarctic and temperate waters and perhaps the southern limit of the Labrador Current at this site (Bohrmann and Stein, 1989). The two main intervals of abundant siliceous microfossils correspond with periods of relatively warm climate (i.e., the Oligocene-Miocene transition and the lower to middle Eocene) (Zachos et al. 2008). These time intervals may have been associated with greater mixing of subantarctic and subtropical waters, which may have promoted biosiliceous productivity at these sites. This scenario is consistent with the low-latitude affinities of the radiolarian assemblages (C.J. Hollis et al., unpubl. data; Jin et al., 2015) and may explain why a time of relatively cooler climatic conditions, from the early Oligocene to late Eocene, is not associated with enhanced biosiliceous productivity in this midlatitude setting. The scarcity of siliceous microfossils at Site U1411 supports this hypothesis. An expanded succession of drift sediments spans the Eocene/Oligocene boundary. Therefore, high burial rates alone cannot account for preservation of siliceous microfossils.

\section{Acknowledgments}

I thank Expedition 342 science and sampling party members and IODP for providing the data and samples used in this report. I thank Kazuyoshi Moriya and Haruka Takagi for their shipboard compilations of siliceous microfossil abundance and Sonja Bermudez for shore-based processing of radiolarian samples at GNS Science. Ted Moore and Dick Norris provided helpful comments on the draft manuscript. Shorebased processing was funded through a postcruise research grant from the Australian and New Zealand
IODP Consortium (ANZIC). My participation in this expedition and preparation of this report was supported by ANZIC and the New Zealand government through the GNS Science Global Change through Time Program (540GCT62) and Marsden Fund Grant (12-GNS-001).

\section{References}

Bohrmann, G., and Stein, R., 1989. Biogenic silica at ODP Site 647 in the southern Labrador Sea: occurrence, diagenesis, and paleoceanographic implications. In Srivastava, S.P., Arthur, M.A., Clement, B., et al., Proceedings of the Ocean Drilling Program, Scientific Results, 105: College Station, TX (Ocean Drilling Program), 155-170. http:// dx.doi.org/10.2973/odp.proc.sr.105.121.1989

Gradstein, F.M., Ogg, J.G., Schmitz, M.D., and Ogg, G.M. (Eds.), 2012. The Geological Time Scale 2012: Amsterdam (Elsevier).

Kamikuri, S., Moore, T.C., Ogane, K., Suzuki, N., Pälike, H., and Nishi, H., 2012. Early Eocene to early Miocene radiolarian biostratigraphy for the low-latitude Pacific Ocean. Stratigraphy, 9(1):77-108. http://www.micropress.org/micropen2/articles/1/7/27546_articles_article_file_1785.pdf

Jin, Y., van Peer, T., Xuan, C., and Hollis, C.J., 2015. Late Oligocene to early Miocene radiolarian events recorded in the mid-latitude North Atlantic [presented at the 14th INTERRAD: International Conference on Fossil and Recent Radiolarians, Antalya, Turkey, 22-26 March 2015].

Moore, T.C., Jr., Jarrard, R.D., Olivarez Lyle, A., and Lyle, M., 2008. Eocene biogenic silica accumulation rates at the Pacific equatorial divergence zone. Paleoceanography, 23(2):PA2202. http://dx.doi.org/10.1029/ 2007PA001514

Moore, T.C., Jr., Wade, B.S., Westerhold, T., Erhardt, A.M., Coxall, H.K., Baldauf, J., and Wagner, M., 2014. Equatorial Pacific productivity changes near the Eocene-Oligocene boundary. Paleoceanography, 29(9):825-844. http:/ /dx.doi.org/10.1002/2014PA002656

Nishimura, A., 1992. Paleocene radiolarian biostratigraphy in the northwest Atlantic at Site 384, Leg 43, of the Deep Sea Drilling Project. Micropaleontology, 38(4):317362. http://dx.doi.org/10.2307/1485764

Norris, R.D., Wilson, P.A., Blum, P., Fehr, A., Agnini, C., Bornemann, A., Boulila, S., Bown, P.R., Cournede, C., Friedrich, O., Ghosh, A.K., Hollis, C.J., Hull, P.M., Jo, K., Junium, C.K., Kaneko, M., Liebrand, D., Lippert, P.C., Liu, Z., Matsui, H., Moriya, K., Nishi, H., Opdyke, B.N., Penman, D., Romans, B., Scher, H.D., Sexton, P., Takagi, H., Turner, S.K., Whiteside, J.H., Yamaguchi, T., and Yamamoto, Y., 2014. Methods. In Norris, R.D., Wilson, P.A., Blum, P., and the Expedition 342 Scientists, Proceedings of the Integrated Ocean Drilling Program, 342: College Station, TX (Integrated Ocean Drilling Program). http://dx.doi.org/10.2204/iodp.proc.342.102.2014 
Norris, R.D., Wilson, P.A., Blum, P., Fehr, A., Agnini, C., Bornemann, A., Boulila, S., Bown, P.R., Cournede, C., Friedrich, O., Ghosh, A.K., Hollis, C.J., Hull, P.M., Jo, K., Junium, C.K., Kaneko, M., Liebrand, D., Lippert, P.C., Liu, Z., Matsui, H., Moriya, K., Nishi, H., Opdyke, B.N., Penman, D., Romans, B., Scher, H.D., Sexton, P., Takagi, H., Turner, S.K., Whiteside, J.H., Yamaguchi, T., and Yamamoto, Y., 2014b. Expedition 342 summary. In Norris, R.D., Wilson, P.A., Blum, P., and the Expedition 342 Scientists, Proceedings of the Integrated Ocean Drilling Program, 342: College Station, TX (Integrated Ocean Drilling Program). http://dx.doi.org/10.2204/ iodp.proc.342.101.2014

Sanfilippo, A., and Nigrini, C., 1998. Code numbers for Cenozoic low latitude radiolarian biostratigraphic zones and GPTS conversion tables. Marine Micropaleontology,
33(1-2):109-117, 121-156. http://dx.doi.org/10.1016/ S0377-8398(97)00030-3

Tucholke, B.E., Vogt, P.R., et al., 1979. Initial Reports of the Deep Sea Drilling Project, 43: Washington, DC (U.S. Govt. Printing Office). http://dx.doi.org/10.2973/ dsdp.proc.43.1979

Zachos, J.C., Dickens, G.R., and Zeebe, R.E., 2008. An early Cenozoic perspective on greenhouse warming and carbon-cycle dynamics. Nature, 451(7176):279-283. http:/ /dx.doi.org/10.1038/nature06588

Initial receipt: 4 February 2016

Acceptance: 16 February 2017

Publication: 2 May 2017

MS 342-201 
Figure F1. Expedition 342 drill sites.

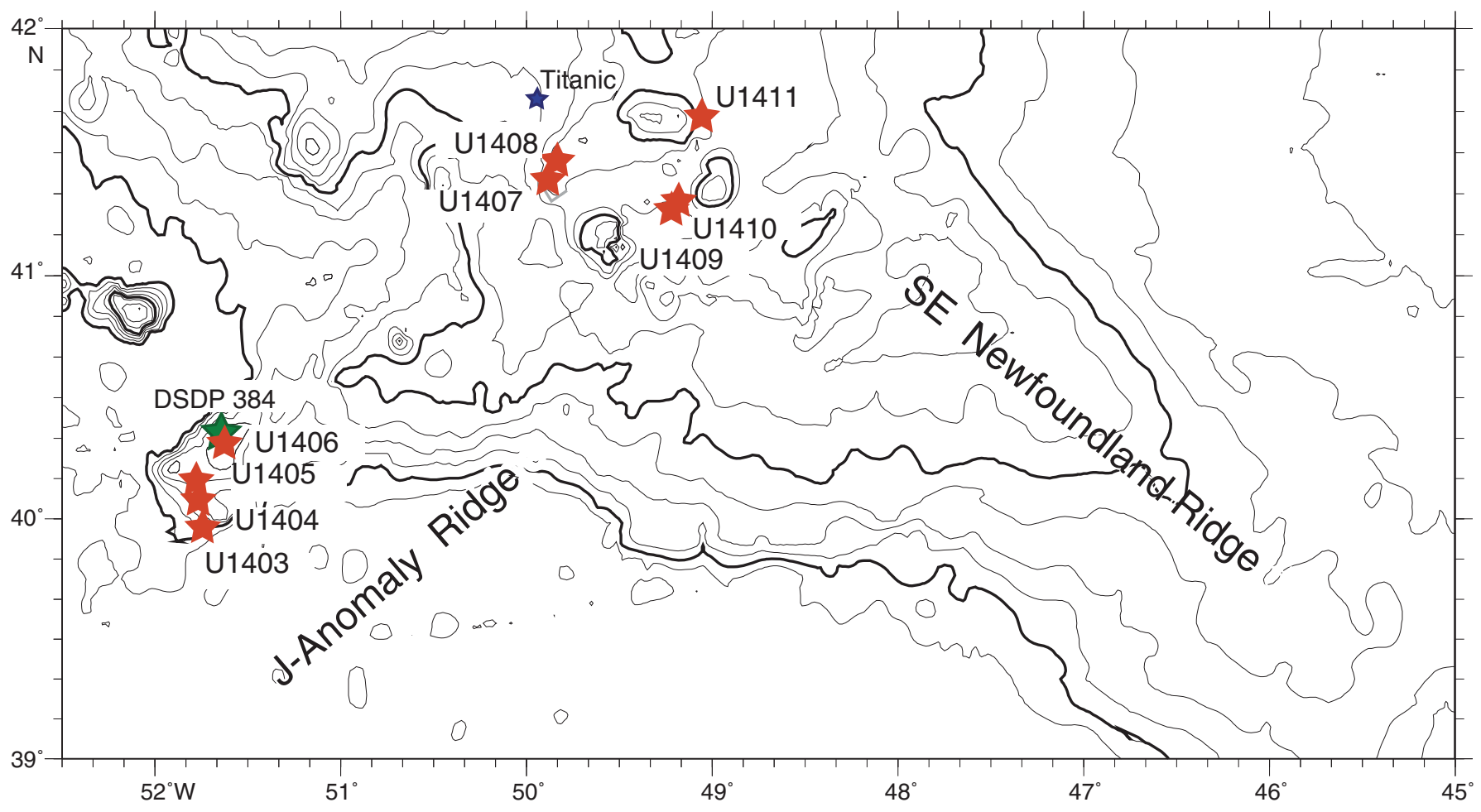


Figure F2. Radiolarian zones, radiolarian abundance and preservation, and siliceous microfossil abundance in smear slides, Hole U1403A.

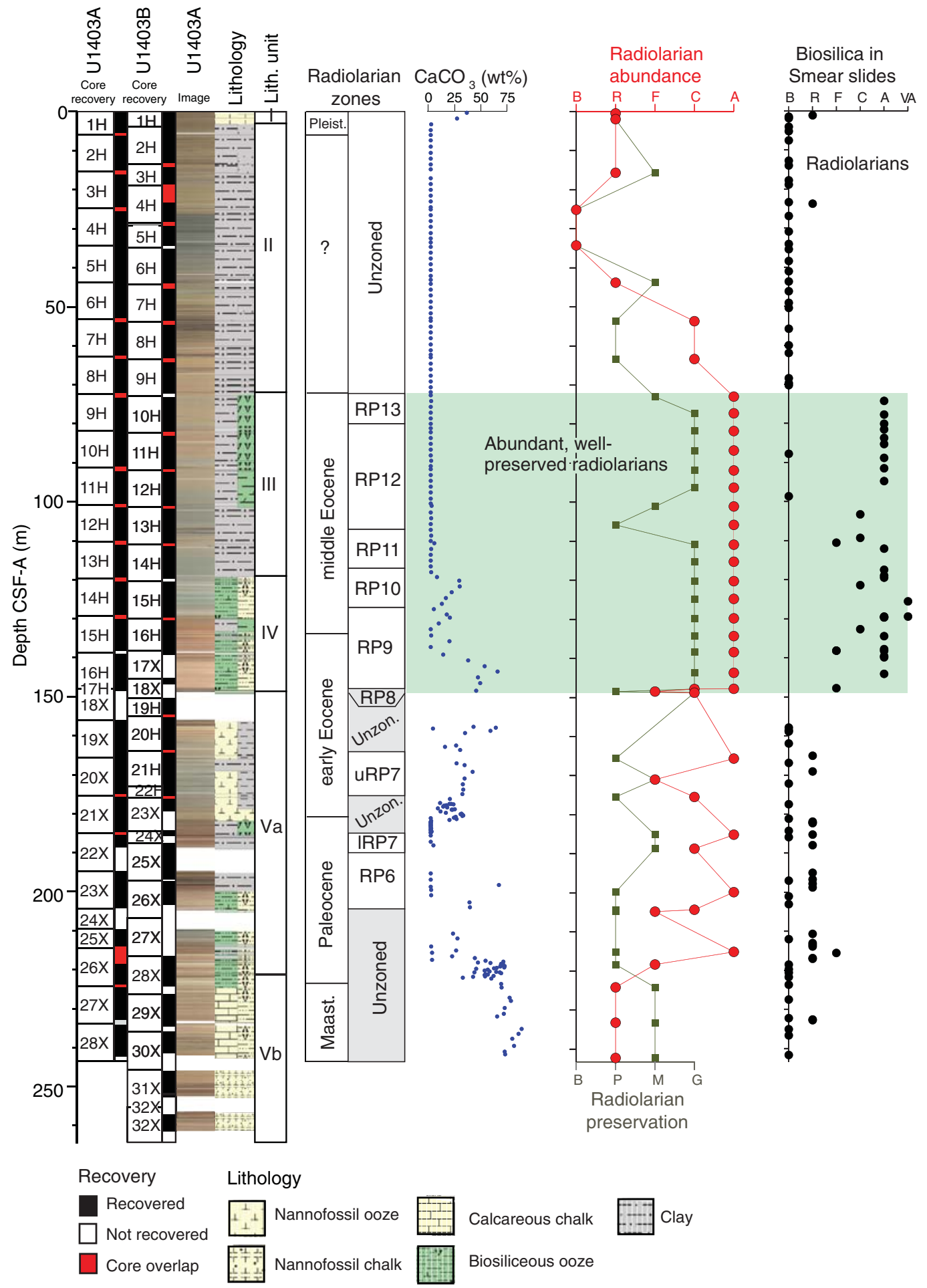


Figure F3. Radiolarian zones, radiolarian abundance and preservation, and siliceous microfossil abundance in smear slides, Hole U1404A.

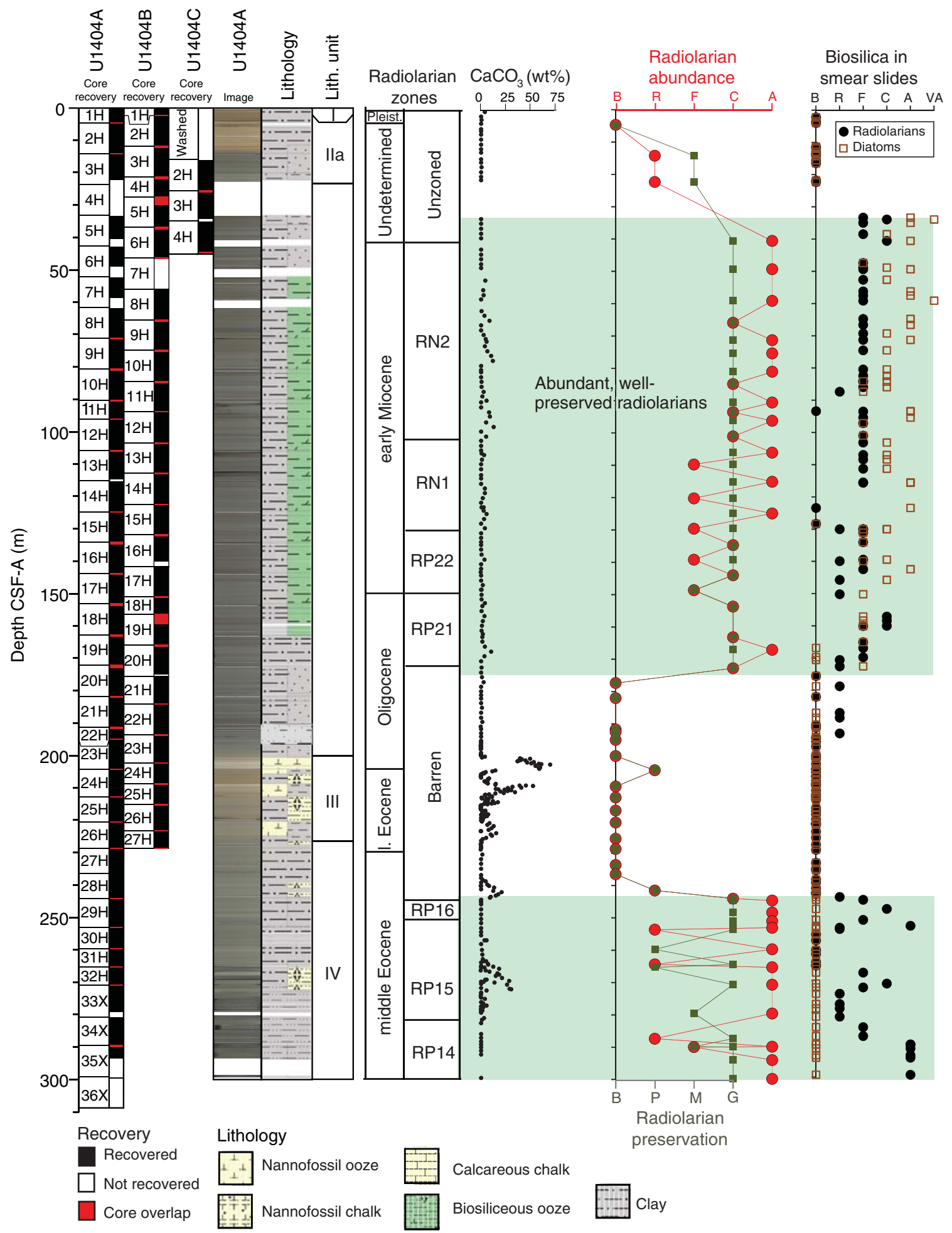


Figure F4. Radiolarian zones, radiolarian abundance and preservation, and siliceous microfossil abundance in smear slides, Hole U1405A.

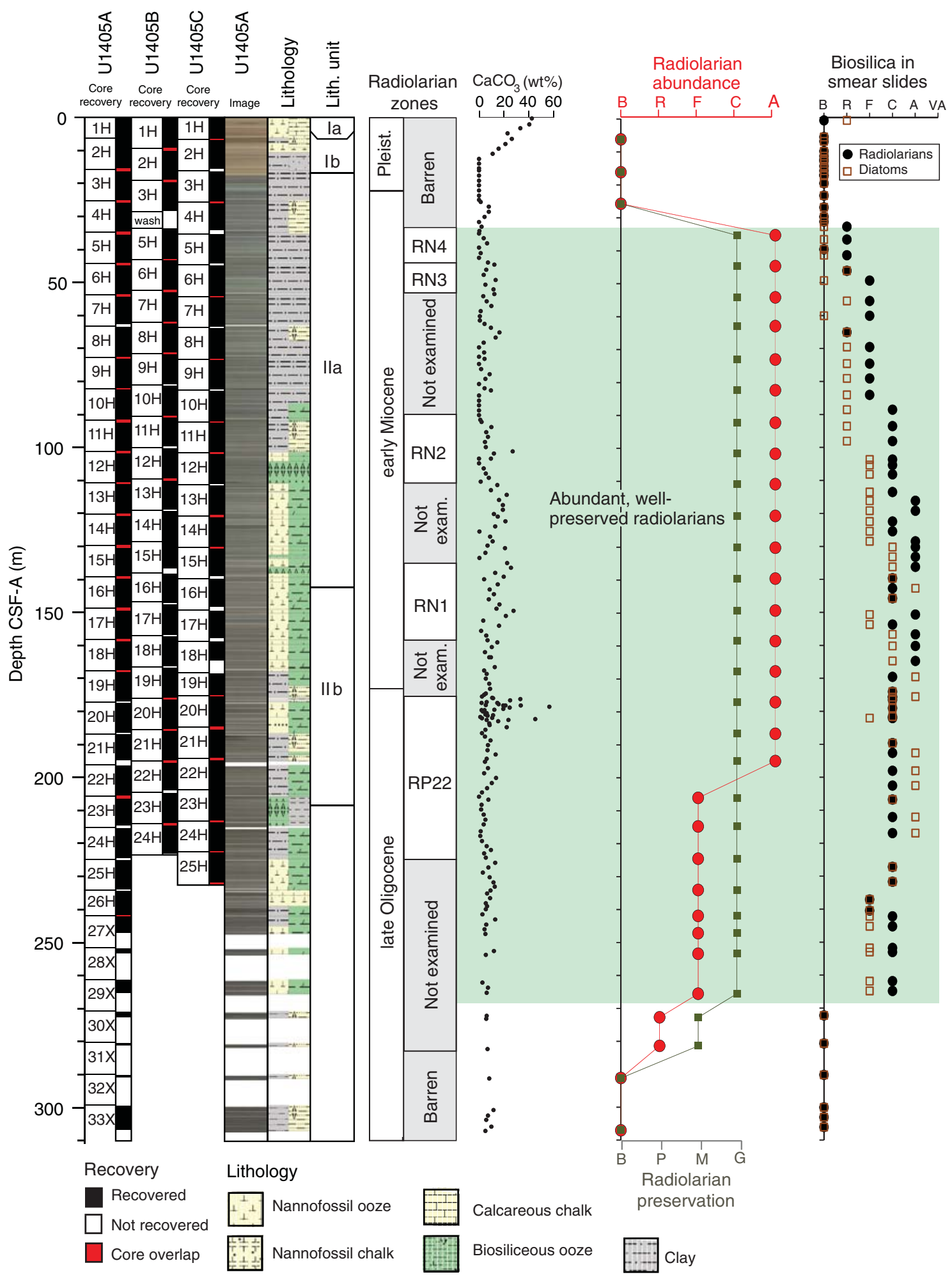


Figure F5. Radiolarian zones, radiolarian abundance and preservation, and siliceous microfossil abundance in smear slides, Hole U1406A.

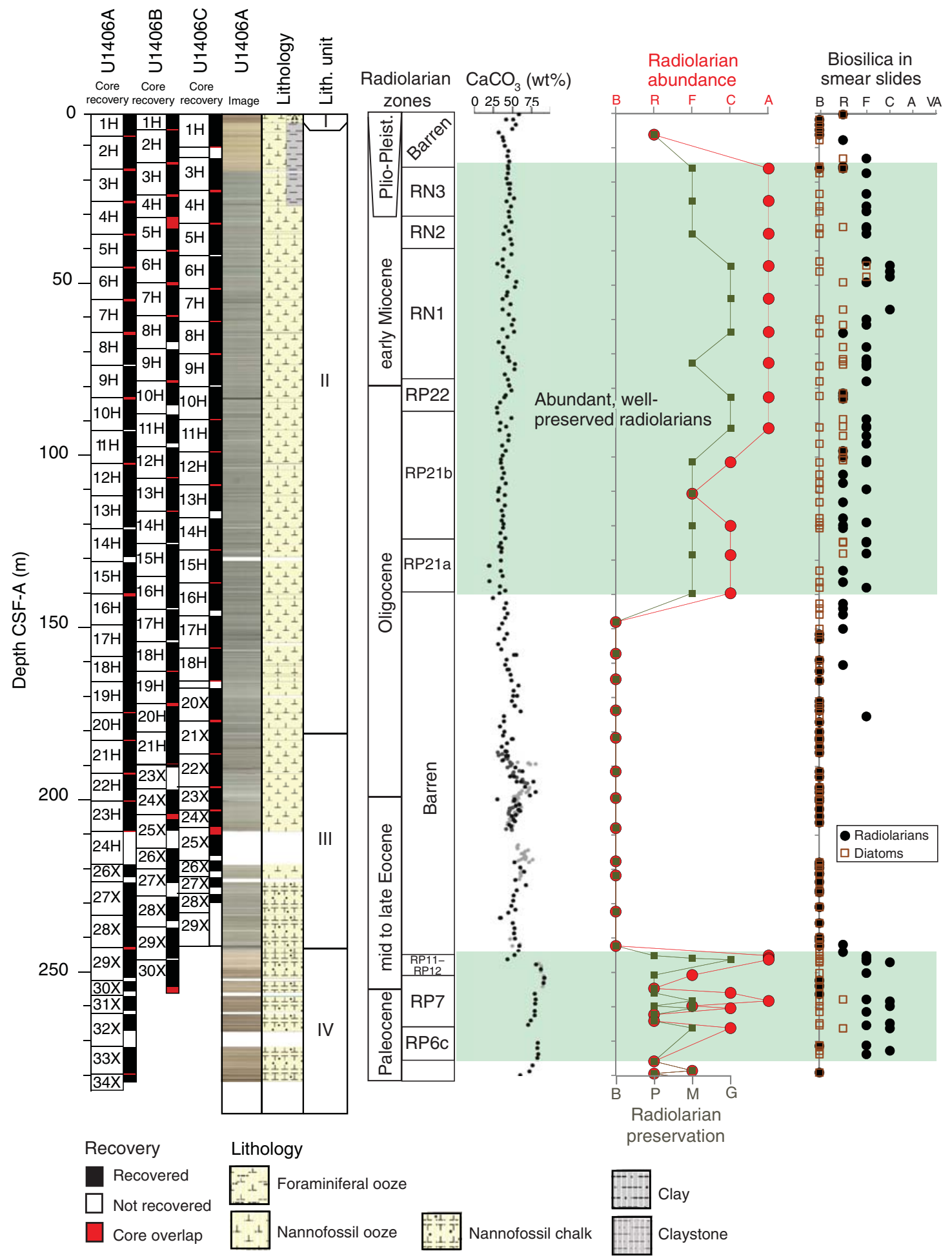


Figure F6. Radiolarian zones, radiolarian abundance and preservation, and siliceous microfossil abundance in smear slides, Hole U1407A.

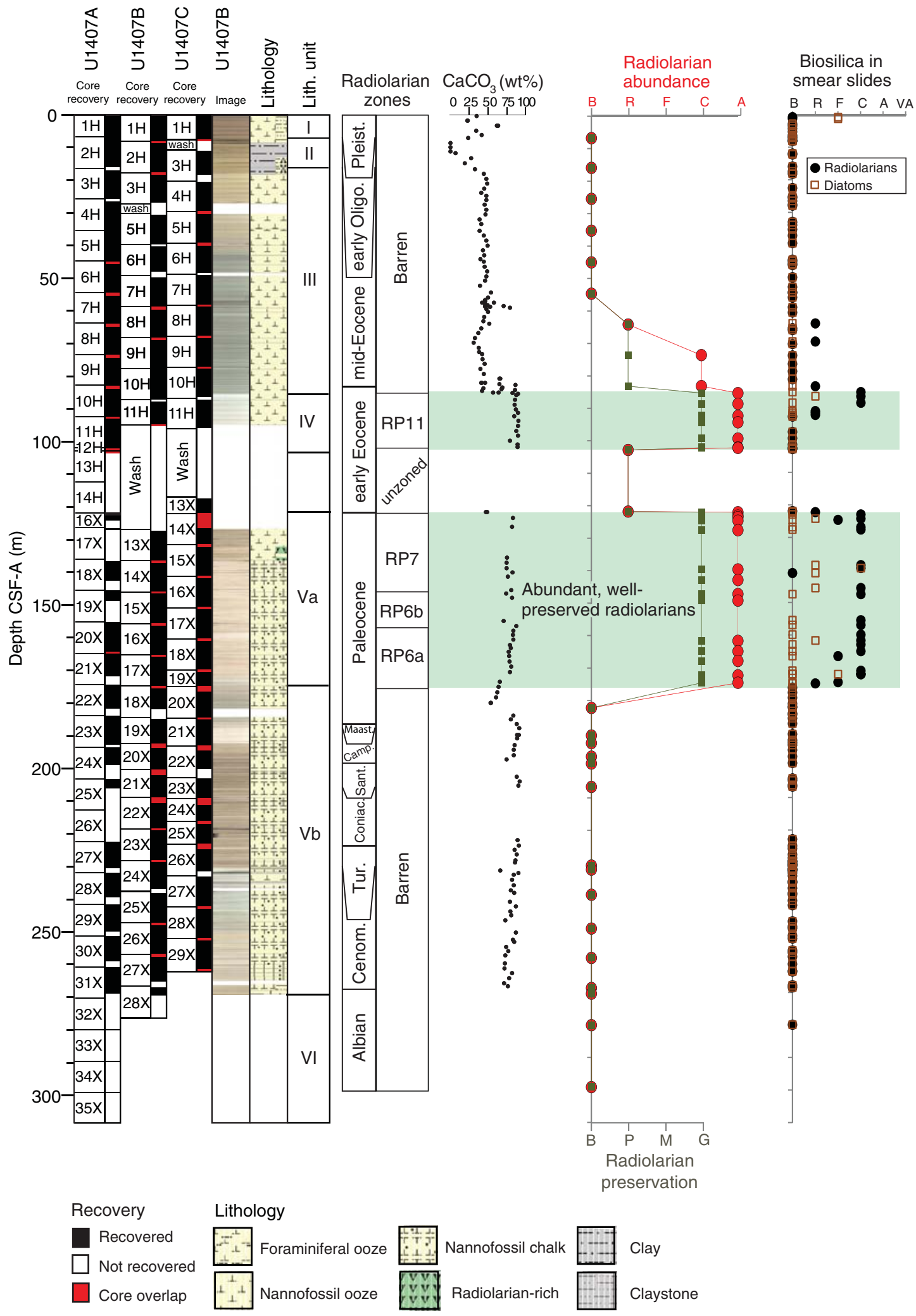


Figure F7. Radiolarian zones, radiolarian abundance and preservation, and siliceous microfossil abundance in smear slides, Hole U1408A.

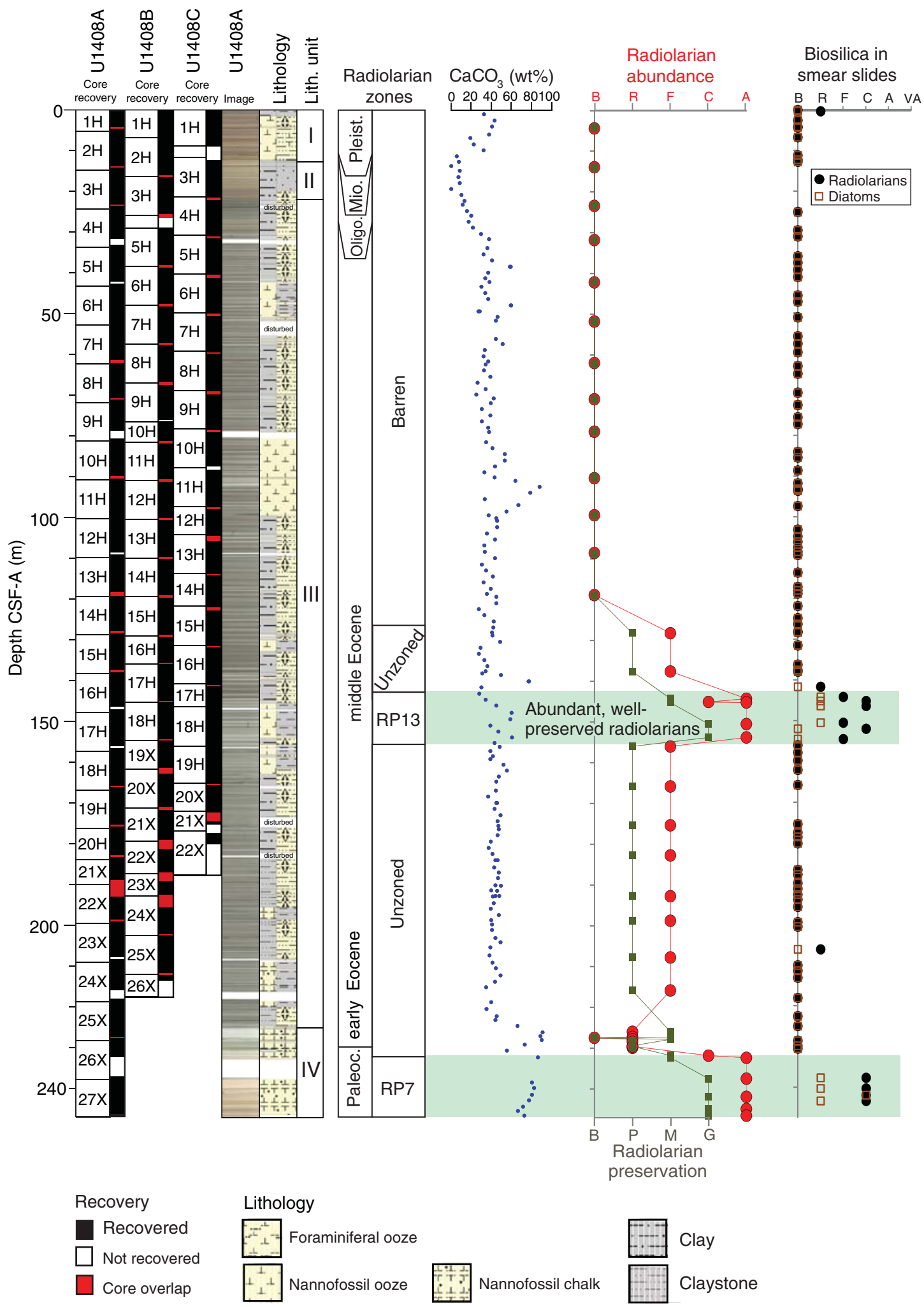


Figure F8. Radiolarian zones, radiolarian abundance and preservation, and siliceous microfossil abundance in smear slides, Hole U1409A.

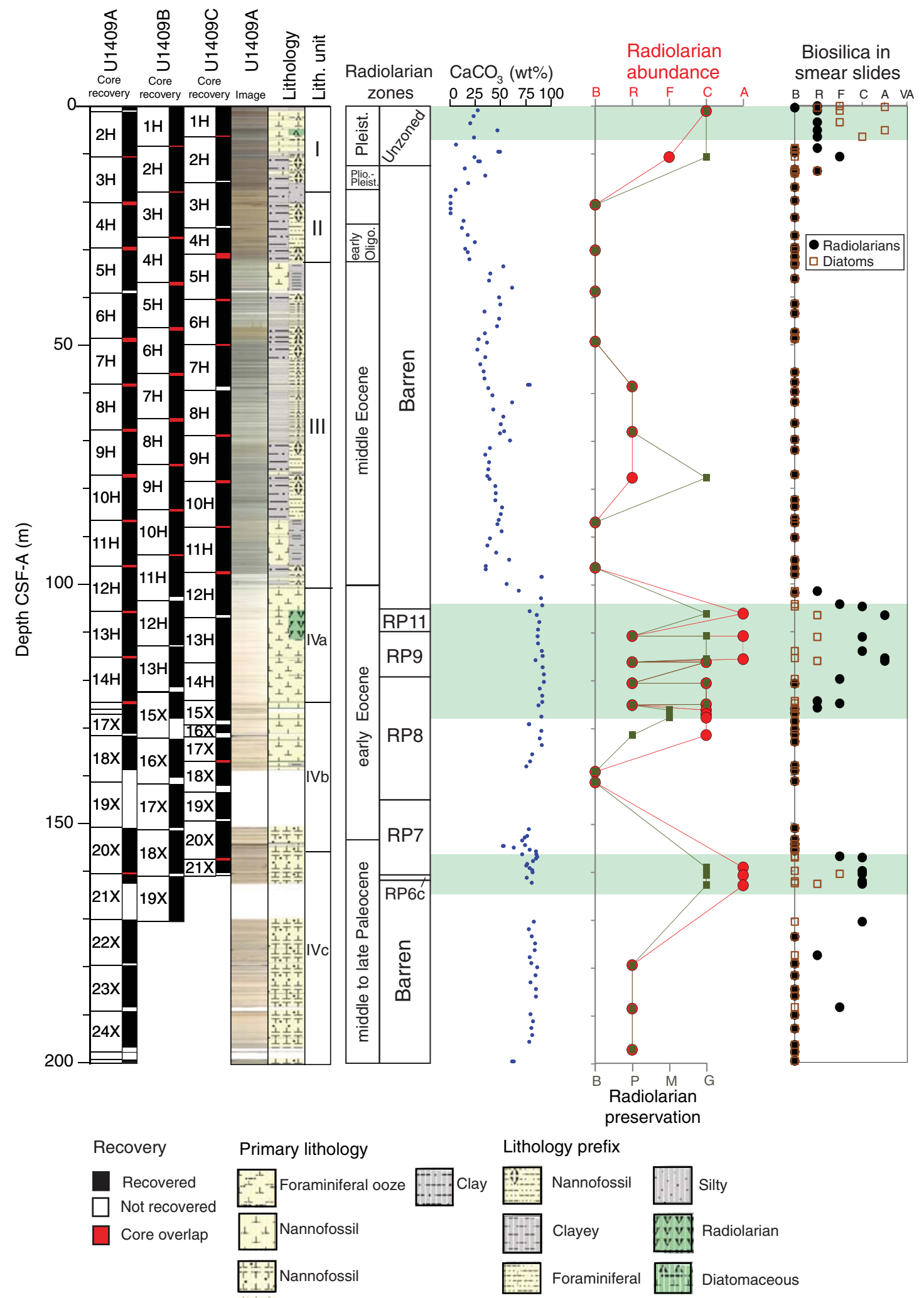


Figure F9. Radiolarian zones, radiolarian abundance and preservation, and siliceous microfossil abundance in smear slides, Hole U14010A.

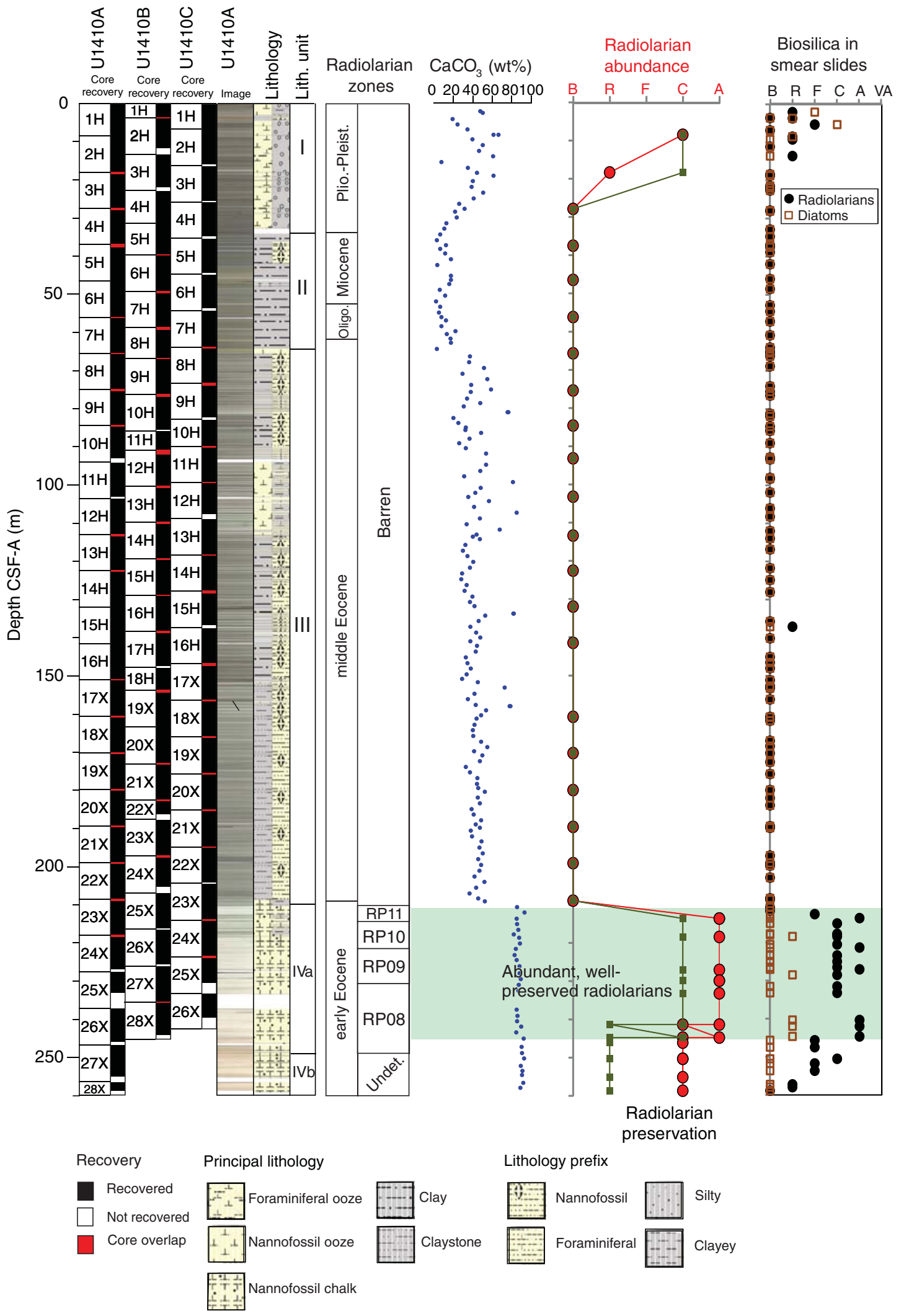


Figure F10. Radiolarian occurrence in relation to linear sedimentation rate curves, Holes U1403-U1410. JAnomaly Ridge sites are underlined. Green bands = intervals of abundant siliceous microfossils.

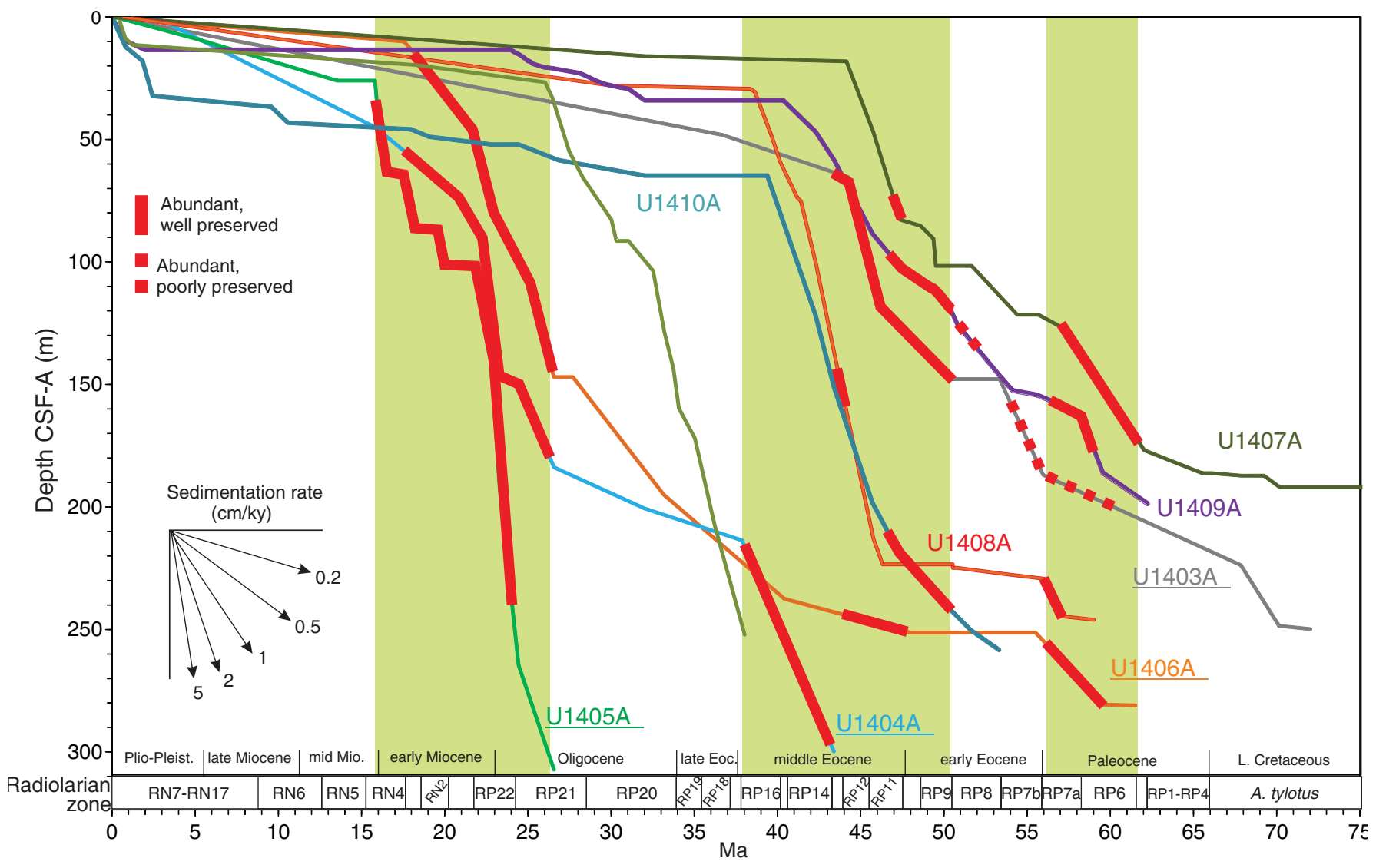

Table T1. Siliceous microfossil abundance. This table is available in CSV format.

Table T2. Radiolarian abundance and preservation. This table is available in CSV format. 